\title{
Comment: Big sagebrush pro versus con
}

\author{
BRUCE L. WELCH
}

Author is principal plant physiologist with the USDA, Forest Service, Intermountain Research Station, Shrub Sciences Laboratory, 735 N. 500 E., Provo, Ut. 84606 .

\section{Key Words: Artemisia tridentata, nutritive value, forage value}

As a self-proclaimed defender of big sagebrush (Artemisia tridentata Nutt.), I am compelled to comment on the article by Ngugi et al. (1995) published in the Journal of Range Management.

My comments center on 2 points: bias in the literature review and the methods used to conduct the experiment.

In my opinion their use of the literature was biased. For example, they stated: "However, the nutritive value of most sagebrush species, including mountain big sagebrush, is still uncertain because of deleterious effects of substances in sagebrush on digestibility (Johnson et al. 1976)." A puzzling statement because the Johnson et al. (1976) study had nothing to do with digestibility. Their concerns were, and I quote from their highlight: "Big sagebrush (Artemisia tridentata) fed to sheep by stomach pump to study its abortifacient properties during the 2nd trimester of pregnancy produced no reproductive difficulties. However, big sagebrush was lethal when $3 / 4 \mathrm{lb}$ was fed by this method daily for 1,2 , or 3 days. Sagebrush fed $1 / 4 \mathrm{lb}$ daily and slowly increased to $3 / 4 \mathrm{lb}$ daily was not toxic." The Johnson et al. (1976) study illustrates the problems that can be encountered when domestic sheep are force-fed ground big sagebrush tissues without a proper adjustment period.

It takes 16 to 20 weeks for sage grouse chicks - an animal that co-evolved with and is a true obligate to big sagebrush-to reach the fall season big sagebrush diet level (66\% to $95 \%)$ of adults (Braun et al. 1977, Klebenow and Gray 1968, Leach and Hensley 1954, Patterson 1952, Peterson 1970, Rasmussen and Griner 1938, Wallestad et al. 1975). Big sagebrush makes up about $15 \%$ of the diet of 10-week-old sage grouse chicks (Braun et al. 1977, Klebenow and Gray 1968, Patterson 1952, Peterson 1970, Rasmussen and Griner 1938). If it takes 16 to 20 weeks for sage grouse to adjust to big sagebrush, why do humans think they can force adjustments on a caged animal-such as sheep that did not co-evolve with big sagebrush-in a few days (Daniel et al. 1993, Holechek et al. 1989, Laycock 1978)?

Another statement by Ngugi et al. (1995) appears biased: "However, the relationship between in vivo digestibility and in vitro digestibility for big sagebrush needs additional study. Of the 13 forages subjected to both in vivo and in vitro digestibility trials for mule deer by Urness et al. (1977), big sagebrush was the only forage for which in vitro digestibility $(62 \%)$ exceeded in vivo digestibility (54\%)" (p. 489). The authors would like the readers to infer that somehow in vitro digestion makes big sage-

This paper was written and prepared by a U.S. Government employee on official time, and therefore is in the public domain and not subject to copyright.

Manuscript accepted 17 Jan. 1996. brush look better than it really is. What they quoted is true. What they did not point out was that the Smith et al. (1966) study, also cited by them, showed just the opposite $-40 \%$ in vitro digestion versus $55 \%$ in vivo digestion.

Another point, if the in vivo digestibilities of the 13 forage samples of the Urness et al. (1977) study were arranged in an array from highest to lowest, big sagebrush would be-fifth. Filaree (Erodium cicutarium (L.) L'Her., spring whole plant, 67\%), curl-leaf mahogany (Cercocarpus ledifolius Nutt. ex Torr. \& Gray, winter twigs and leaves, 64\%), mesquite (Prosopis juliflora Torr., fruit $60 \%$ ), and desert ceanothus (Ceanothus greggii Gray, leaves 55\%) are the 4 forage samples out of 13 that exceeded in vivo digestion of big sagebrush winter leaves and stems. Big sagebrush exceeded 8 of 13 forage samples. So, $54 \%$ in vivo dry matter digestion of sagebrush winter leaves and stems is good compared to other forages.

In addition, it could be possible that the in vivo techniques used by Ngugi et al. (1995) underestimated the value of big sagebrush as a forage plant.

Again, Ngugi et al. (1995) stated: "Big sagebrush also contains highly lignified, indigestible cell walls, surrounding a large and relatively digestible fraction of cell solubles (Kufeld et al. 1981)" (p. 489). The content of big sagebrush lignin in Kufeld et al. (1981) was $12 \%$ compared to $24 \%$ in Gamble oak (Quercus gambelii Nutt.). Lignin content of other forages that exceed big sagebrush are: $13 \%$ timothy hay (Phleum pratense L.) sun cured very mature; 14\% smooth brome hay (Bromus inermis Leyss.) mature; 15\% crested wheatgrass (Agropyron desertorum (L.) Gartn.) early bloom; $17 \%$ bluestem wheatgrass ( $A$. smithii Rydb.) forage very mature; $21 \%$ snowberry (Symphoricarpos spp.); $13 \%$ shadscale (Atriplex confertifolia (Torr. \& Frem.) Wats.) dormant; and $13 \%$ red clover (Trifolium pratense Steb. \& Sch.) hay (National Research Council 1958, 1964). Are there forages that contain less than $12 \%$ lignin? Absolutely! So what's the point? The point is those who dislike big sagebrush will point out the weaknesses and those who like big sagebrush the strengths. Who is right? Both are!

Yes, big sagebrush tissues contain substances that have anticellulolytic properties, but they also have large, highly digestible amounts of cellular content. Several studies have demonstrated the loss of essential or volatile oils from ingesta of a number of animals (Cluff et al. 1982, Foley et al. 1987, Narjisse 1981, Welch et al. 1989, White et al. 1982). Yet, Ngugi et al. (1995) have totally ignored these mitigating factors. Hobbs et al. (1986) —cited by Ngugi et al. (1995)—-suggested another mitigating factor. Van Soest (1994) states: "Some plants high in essential oils-for example, sagebrush (Artemisia)-are known to possess anticellulolytic principles, but browsing ruminants can adapt 
and detoxify these compounds."

In addition to bias in their literature review, I believe that the methods and materials used to conduct the experiment were biased against big sagebrush. These methods and materials were the use of big sagebrush leaves (p. 487), grinding of the sagebrush tissues (p. 487), and use of mature grass (p. 478).

Leaves contain higher levels of essential or volatile oils than leaves and stems, or stems alone. Feeding leaves alone would expose the consuming animal to a greater concentration of essential or volatile oils than a mixture of leaves and stems. Domestic sheep I have watched feeding on big sagebrush consumed both leaves and stems, just as do native shrubland animals such as pronghorn antelope (Antilocapra americana), mule deer (Odocoileus hemionus hemionus), etc. Wintering sage grouse (Centrocercus urophasianus) is the only animal I know of whose diet consists of nearly $100 \%$ big sagebrush leaves (Patterson 1952). Ironically, this occurs at a time (winter) when they are gaining weight (Patterson 1952, Beck and Braun 1978). Of course, sage grouse are not ruminants but do depend on microbes in their cecum for digestion of cellulose (Leopold 1953).

Grinding of big sagebrush tissues releases greater amounts of essential or volatile oils faster than normal bite sizes. This release could intensify the adverse effects of essential or volatile oils beyond the real world. Smith et al. (1966), however, when they ground sagebrush tissues for their in vivo digestion trials, reported: "The addition of sagebrush by mechanical means in Trial 3 did not result in lowered digestibility values, indicating that lambs utilized sagebrush quite satisfactorily as one-half of their diet." So, we have 2 in vivo digestion studies-Ngugi et al. (1995), and Smith et al. (1966) - that ground sagebrush tissues but came to opposite conclusions. Who's right? The answer is as variable as populations of mountain big sagebrush, as variable as the feeding experiences of the test animals, and as variable as the manners/conditions in which the materials were prepared and handled by the experimenters.

A final point: The objective of the Ngugi et al. (1995) study was to determine the effects of big sagebrush on grass digestion. Question: How much mature grass do wintering animals of western shrublands such as mule deer, pronghorn antelope, sage grouse, pygmy rabbits (Brachylagus idahoensis), etc. consume? Not much (Wallmo 1981, Smith and Beale 1980, Patterson 1952, Green and Flinders 1980).

To answer the question posed by Bastian et al. (1995) in their title, "How much sagebrush is too much," depends on if you are grazing livestock on western shrublands or one of many organisms such as sage grouse that depend on big sagebrush for their very existence.

\section{Literature Cited}

Bastian, C.T., J.J. Jacobs, and M.A. Smith. 1995. How much sagebrush is too much: An economic threshold analysis. J. Range Manage. 48:73-80.

Beck, T.D. and C.E. Braun. 1978. Weights of Colorado sage grouse. Condor 80:241-243.

Braun, C.E., T. Britt, and R.O. Wallestad. 1977. Guidelines for maintenance of sage grouse habitats. Wildl. Soc. Bull. 5:99-106.

Cluff, L.K., B.L. Welch, J.C. Pederson, and J.D. Brotherson. 1982. Concentration of monoterpenoids in the rumen ingesta of wild mule deer. J. of Range Manage. 35:192-194.
Daniel, A., J.L. Holechek, R. Valdez, A. Tembo, L. Saiwana, M. Rusco, and M. Cardenas. 1993. Range condition influences on Chihuahuan Desert cattle and jackrabbit dicts. J. Range Manage. 46:296-301.

Foley, W.J., E.U. Lassak, and J. Brophy. 1987. Digestion and absorption of Eucalyptus essential oils in greater glider (Petauroides volans) and the brushtail possum (Trichosurus vulpecula). J. Chem. Ecol. 13:2115-2130.

Green, J.S. and F.T. Flinders. 1980. Habitat and dietary relationships of the Pygmy Rabbit. J. Range Manage. 33:136-142.

Hobbs, N.T., B.L. Welch, and T.E. Remington. 1986. Effects of big sagebrush on in vitro digestion of grass cell walls. p. 186-189. In: E.D. McArthur and B.L. Welch (compilers). Proc., Symp. on the Biology of Artemisia and Chrysothamnus. USDA For. Serv. Gen. Tech. Rep. INT200, Ogden, Ut.

Holechek, J.L., R.D. Pieper, and C.H. Herbel. 1989. Range Management principles and practices. Regents/Prentice Hall, Englewood Cliffs. N.J.

Johnson, A.E., L.F. James, and J. Spillett. 1976. The abortifacient and toxic effects of big sagebrush (Artemisia tridentata) and Juniper (Juniperus osteoperma) on domestic sheep. J. Range Manage. 29:278-280.

Klebenow, D.A. and G.M. Gray. 1968. Food habits of juvenile sage grouse. J. Range Manage. 21:80-83.

Kufeld, R.C., M.S. Stevens, and D.C. Bowden. 1981. Winter variation in nutrient and fiber content and in vitro digestibility of Gambel oak (Quercus gambellii) and big sagebrush (Artemisia tridentata) from diversified sites in Colorado. J. Range Manage. 34:149-151.

Laycock, W.A. 1978. Coevolution of poisonous plants and large herbivores on rangelands. J. Range Manage. 31:335-342.

Leach, H.R. and A.L. Hensley. 1954. The sage grouse in California, with special reference to food habits. Calif. Fish and Game. 40:385-394.

Leopold, A.S. 1953. Intestinal morphology of gallinaceous birds in relation to food habits. J. Wild. Manage. 17:197-203.

Narjisse, H. 1981. Acceptibility of big sagebrush to sheep and goats: Role of monoterpenes. Ph.D. Diss., Utah State University, Logan, Ut.

National Research Council. 1958. Composition of cereal grains and forages. Publication 585, National Academy of Sciences-National Research Council, Washington, D.C.

National Research Council. 1964. Nutrient requirements of sheep. Publication 1193, National Academy of Sciences-National Research Council, Washington, D.C.

Ngugi, R.K., F.C. Hinds, and J. Powell. 1995. Mountain big sagebrush browse decreases dry matter intake, digestibility, and nutritive quality of sheep diets. J. Range Manage. 48:487-492.

Patterson, R.L. 1952. The Sage Grouse in Wyoming. Sage Books, Inc., Denver. Colo.

Peterson, J.G. 1970. The food habits and summer distribution of juvenile sage grouse in Central Montana. J. Wildl. Manage. 34:147-155.

Rasmussen, D.I. and L.A. Griner. 1938. Life history and management studies of the sage grouse in Utah, with special reference to nesting and feeding habits. 3rd North American Wildl. Conf. 3:852-864.

Smith, A.D. and M.D. Beale. 1980. Antelope in Utah. Utah Division of Wildlife Resources Publ. 80-13. Salt Lake City, Ut.

Smith, G.E., D.C. Church, J.E. Oldfield, and W.C. Lightfoot. 1966. Effect of sagebrush on forage digestibility by lambs. Proc. West. Sec. Amer. Soc. Anim. Sci. 17:373-378a.

Urness, P.J., A.D. Smith, and R.K. Watkins. 1977. Comparison of in vivo and in vitro dry matter digestibility of mule deer forages. J. Range Manage. 30:119-121.

Van Soest, P.J. 1994. Nutritional ecology of the ruminant, 2nd edition. Cornell University Press, Ithaca, N.Y.

Wallestad, R., J. Peterson, and R.L. Eng. 1975. Foods of adult sage grouse in Central Montana. J. Wildl. Manage. 39:628-630.

Wallmo, O.C. 1981. Mule and Black-tailed Deer of North America. University of Nebraska Press, Lincoln, Neb.

Welch, B.L., J.C. Pederson, and R.L. Rodriguez. 1989. Monoterpenoid content of sage grouse ingesta. J. Chem. Ecolo. 15:961-969.

White, S.M., B.L. Welch, and J.T. Flinders. 1982. Monoterpenoid content of pygmy rabbit stomach ingesta. J. Range Manage. 35:107-109. 